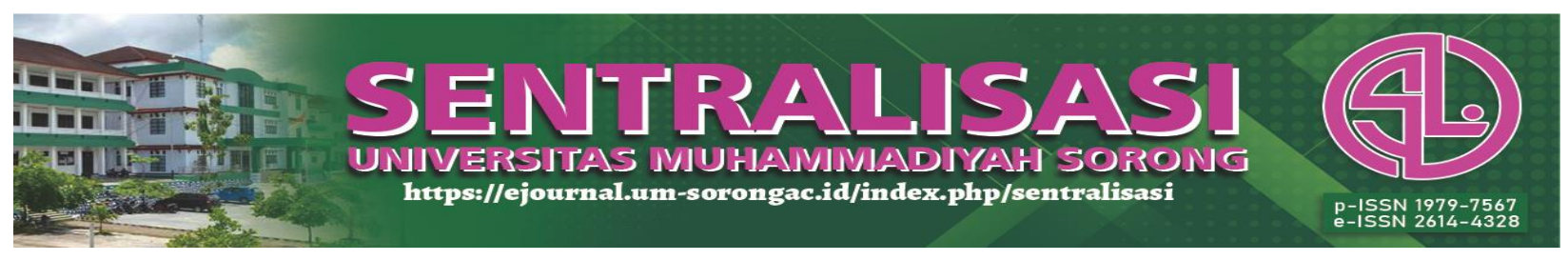

\title{
The Effect of Organizational Commitment on Service Performance: An Empirical Study at Public Health Center in Sorong Regency
}

\author{
Reijeng Tabara ${ }^{1}$, Rahmad Hidayat Dongka ${ }^{2}$ \\ ${ }^{1,2}$ Fakultas Ilmu Sosial dan Keguruan, Universitas Nani Bili Nusantara, Indonesia \\ E-mail : regentabara@gmail.com
}

direvisi: 28/12/2020 dipublikasikan: 31/01/2021

\begin{abstract}
Abstrak. . Tujuan dari penelitian ini adalah untuk mengetahui pengaruh komitmen organisasi terhadap kinerja layanan pada puskesmas kabupaten sorong. Penelitian ini menggunakan Partial Least Squares (PLS) dengan teknik Structural Equation Modeling (SEM) untuk menganalisis 146 pegawai. Hasil penelitian menunjukkan terdapat pengaruh positif dan signifikan antara komitmen organisasi terhadap kinerja layanan dengan nilai $\mathrm{T}_{\text {statistik }}$ lebih besar dari $\mathrm{T}_{\text {tabel }}\left(\mathrm{T}_{\text {statistik }} 39,288>\mathrm{T}_{\text {tabel }} 1,976\right)$ pada taraf signifikansi sebesar 5\% $(0,05)$. Hasil studi ini mengindikasikan bahwa semakin tinggi komitmen organisasi yang dimiliki pegawai, maka akan semakin meningkatkan kinerja layanan pada puskesmas kabupaten sorong Papua Barat.
\end{abstract}

Kata kunci: Komitmen Organisasi, Kinerja Layanan, Puskesmas

Abstract. This study aims to determine the effect of organizational commitment on service performance in health centers all around Sorong district. This study was using Partial Least Squares (PLS) with Structural Equation Modeling (SEM) techniques to analyze 146 employees. The results showed that there was a positive and significant influence between organizational commitment to service performance with a $T$ statistic value greater than T-table (T-statistic 39.288> T-table 1.976) at a significance level of 5\% (0.05). The results of this study have indicated that the higher the organizational commitment of employees, the better the service performance at health centers in Sorong district, West Papua.

Keywords: Organizational Commitment, Service Performance, Public Health Center

\section{Introduction}

As far it knows, the impact of a particular autonomy in a region exists to the strengthening of a regional government authority. This impact is such the form of planning and implementation of self-government affairs which leads to the practical local government will be more creative and innovative. However, the fundamental issue with the existence of special autonomy in Papua is how local government services can accommodate the community, in particular with those related to public health services. Till these days, the local government has attempted to make innovative breakthroughs by generating a series of creative initiatives, so that five main points become references in determining service performance indicator assessments, especially in the public health sector, which refers to the Fajar Institute of Pro-autonomy scheme (FIPO). The first indicator is the accessibility of services in the public health sector, which includes easy, low cost, affordable and fair services; Second, the availability of professional health personnel with the support of facilities and infrastructure; Third, the health protection system; Fourth, health budget commitment; and fifth, the participation of health service providers.

According to Shaw et al., (2013) and Chung \& Schneider, (2002), Service performance is the main front line by which an organization can reach a competitive advantage. Kotler, (2012); 


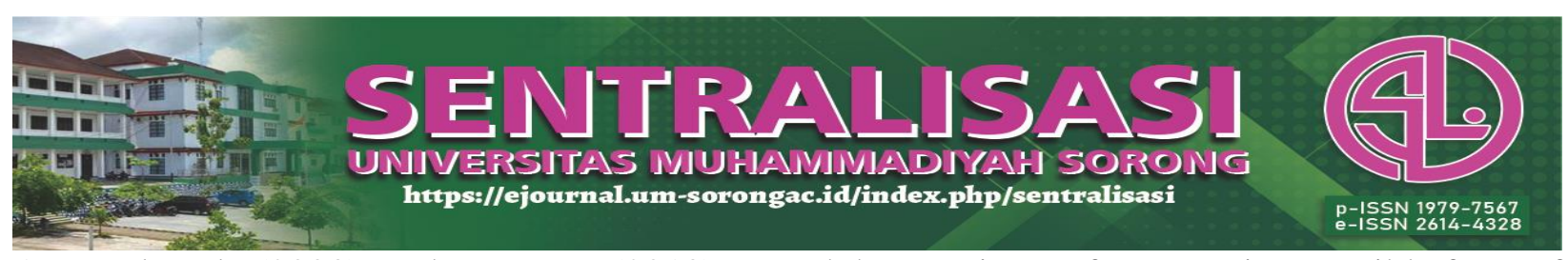

Agarwal et al., (2003); and Karatepe, (2013) argued that service performance is a tangible form of an action or activity that can be offered by the service provider to the service recipient, which is without a concrete form and does not lead to service ownership of the service provided to meet user expectations, service is also crucial factor and benchmarks for achieving organizational excellence and increase people's trust. To increase organizational quality Huang \& Dai, (2010) explained that employees evaluate service performance because the impact of employees' emotional state and laborers' perceptions on their service performance is generally abstract, this cannot be measured easily and objectively by others, therefore it requires a strong commitment from employees.

Studies on employee commitment have been conducted, but do not further explain the context in increasing service performance. As the results of research by Menon et al., (1996) acknowledged that organizational commitment does not affect organizational performance and service performance. Furthermore, the study conducted by Sarwat et al., (2011) found that there was no significant relationship between commitment and increased organizational performance. The same research result was also found by Subejo, (2013)where organizational commitment has not been able to contribute to maximizing performance. Resourced-Based Theory reveals that commitment is the most important carriage where the organization's resources and capabilities are able to determine the relationship to create teamwork behavior in the organization through a crossfunctional integration process and trigger good and positive process synergies so that it will result in an organization's sustainably superior service performance improvement (Das \& Teng, 2000; Kozlenkova et al., 2014; Porter et al., 2007).

The regional government commitment of Sorong, West Papua Province, to improving public health services is evident in the complimentary health program. The chargeless health program is seemingly a breath of fresh air to the people of Sorong Regency. The program received a warm welcome from the community by visiting these service centers. The communities' enthusiasm of Sorong Regency in visiting health service centers proves that the concept of a free health program is needed by the community, especially for those who care about their health. It can be identified from an increase in the number of visitors to the program, and it should be noted that the center for the gratuitous health program launched by the government in 2014 is at the public health center and third-class referral hospital level.

By getting the gratuitous health program that has been accepted by the community, it has not been able to offer much hope and satisfaction to health workers who are responsible for providing health services. In certain cases that occur in the community, there is still dissatisfaction received by the community with complaints from both the friendliness of the officers, the timeliness of services, complicated administration, discrimination, to the level of cleanliness of the public health surroundings that do not support sanitation standards. It can be said that the free health program launched by the government has not yet provided a satisfactory standard in the community even 


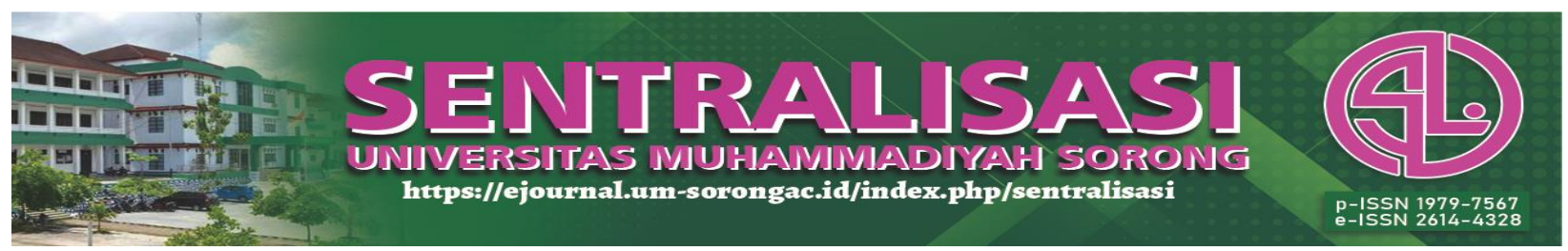

though it holds the concept of free of cost which certainly eases the community. It can be aforementioned that the regional government of Sorong Regency has not succeeded in realizing a maximum of health services. On the other hand, the local government is required to be able to conceive new work innovations that are more creative in enhancing health services, particularly the commitment of officers involved in offering good services.

This research study focuses on the health service organization, especially the public health center in the Sorong regency by identifying methodological issues of the effect of the relationship between organizational commitments in improving service performance at the health centers in Sorong regency, West Papua.

\section{Research Method}

The type of this research used was an explanatory research method. Sources of data using primary data obtained from questionnaires distributed to respondents containing respondents' responses to research variables. The population in the study were all employees who worked at Health Center in Sorong regency. The sampling technique employed was the purposive sampling method concerning the maximum likelihood (ML) estimation model, the sample size was around 100-200 samples (Ferdinand, 2011), referred to the 150 questionnaires distributed, 146 of them can be continued to the analysis stage due to the completeness of the respondents' answers.

The total questionnaire consisted of 9 items. All items were measured using a 5-point Likert scale where $1=$ strongly disagree and $5=$ strongly agree. The service performance variables in this study are gauged through six indicators, namely tangibility, reliability, responsiveness, assurance, empathy, and equity (Kotler, 2012; Parasuraman et al., 1988). The organizational commitment variables are measured through three indicators, namely feeling proud of the organization, concern for the organization, ability and desire to do business for the organization (Ivancevich, J., Konopaske, R., \& Matteson, 2012). Furthermore, the data analysis technique employed was the Structural Equation Model (SEM) with the assistance of the Smart PLS 2.0 M3 program (Hair, J. F.; Black, W. C.; Babin, B. J.; Anderson, 2014; Ringle et al., 2005).

\section{Result and Discussion}

\section{Results of PLS Analysis}

Analyzing Outer model loading factor or Path Coefficient Test

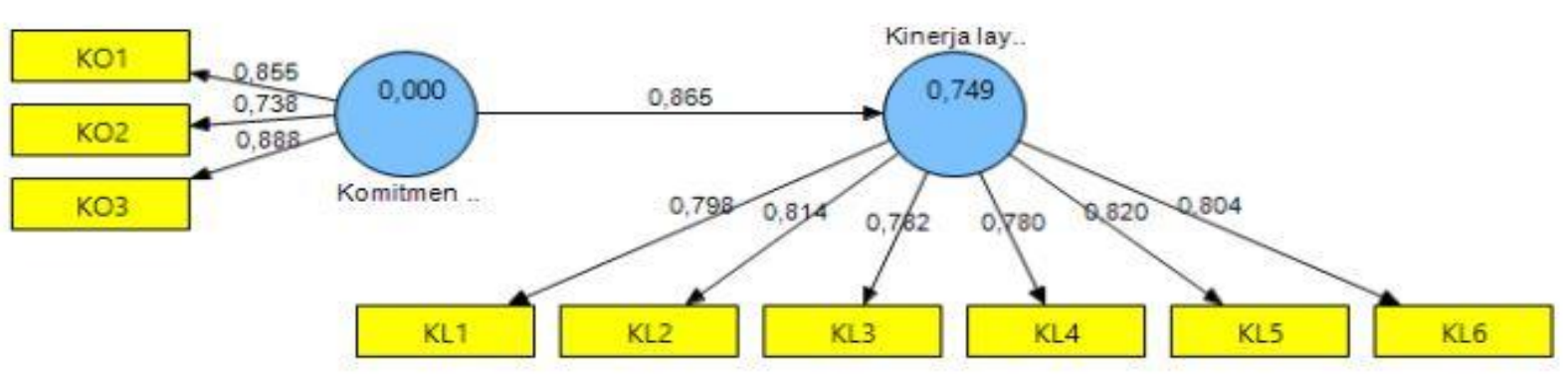

Figure 1. Full Outer Model 


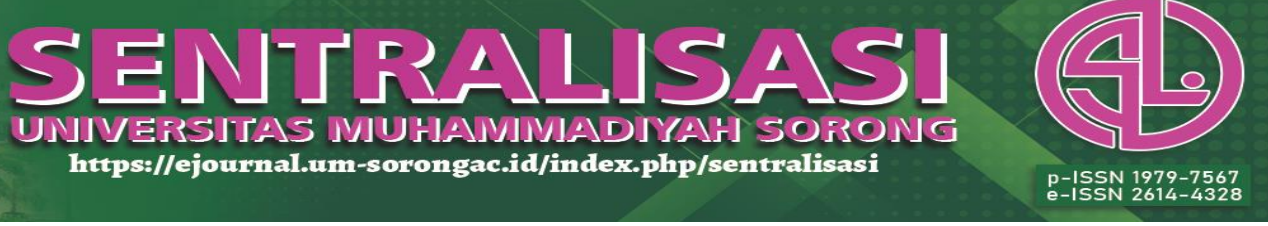

Figure 1 indicates that the two research variables are constructed by indicators that meet the requirements or are valid. The indicator is said to meet the requirements if the loading factor value is greater than 0.5 with the construct measured against the intended construct. In the figure provided above, the organizational commitment variable is constructed by three indicators (KO1, $\mathrm{KO}$, and $\mathrm{KO} 3$ ) with the largest loading factor value on the $\mathrm{KO} 3$ indicator (Ability and desire to do business for the organization) of 0.888 , and the service performance variable was constructed by six indicators (KL1, KL2, KL3, KL4, KL5, and KL6) with the largest loading factor value on the KL5 indicator (Empathy) of 0.820.

Furthermore, the validity test result refers to the convergent value or discriminant validity by looking at the factor loading values and confirmed by the square root of average variance extracted (AVE) value, and the reliability test was determined by the value of composite reliability by each variable and confirmed by the Cronbach's Alpha value Alpha (Hair, J. F.; Black, W. C.; Babin, B. J.; Anderson, 2014). Each value is shown in table 2 of the following measurement model results:

Table 2. Measurement Model Results

\begin{tabular}{lllll}
\hline $\begin{array}{l}\text { Constructed } \\
\text { Variables }\end{array}$ & $\begin{array}{l}\text { Factor } \\
\text { loadings }\end{array}$ & $\begin{array}{l}\text { Square Root of } \\
\text { Average Variance } \\
\text { Extracted (AVE) }\end{array}$ & $\begin{array}{l}\text { Composite } \\
\text { Reliability }\end{array}$ & $\begin{array}{l}\text { Cronbach's } \\
\text { Alpha }\end{array}$ \\
\hline Service Performance & & 0.639626 & 0.914131 & 0.889089 \\
KL1 & 0.798210 & & \\
KL2 & 0.813982 & & \\
KL3 & 0.781743 & & \\
KL4 & 0.780160 & & \\
KL5 & 0.820076 & & \\
KL6 & 0.803587 & & \\
Organizational & & 0.868081 & \\
\multicolumn{1}{c}{ Commitment } & & & \\
KO1 & 0.688157 & & \\
KO2 & 0.738103 & & \\
KO3 & 0.887875 & & \\
\hline
\end{tabular}

Source: Primary Data Processed in 2020

Table 2 shows that the result of the outer loading of each indicator in each construct has a value greater than 0.5 so that it can be declared valid and can be used to gauge the variables of organizational commitment and service performance. Besides, the Square Root of the Average Variance Extracted (AVE) value is also higher than 0.5 so that the convergent validity measurement requirements have been met. Therefore all questionnaire items can be used to analyze 


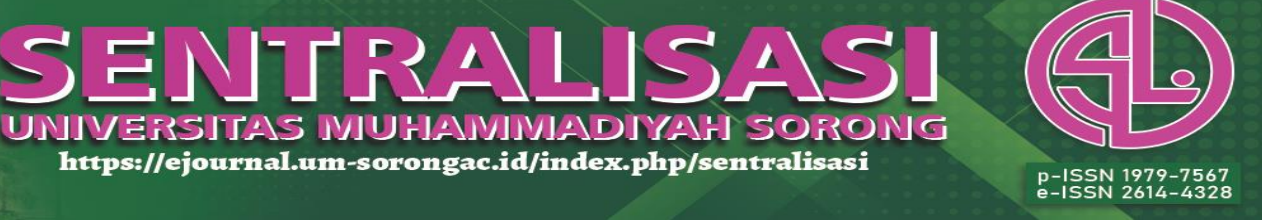

the results of this study. Furthermore, composite reliability is used to test the reliability of indicator variables. Based on the information presented in Table 2, it can be seen that the composite reliability value of all research variables is above 0.6, this result shows that each variable has met a high level of reliability.

Inner Model and t-Test

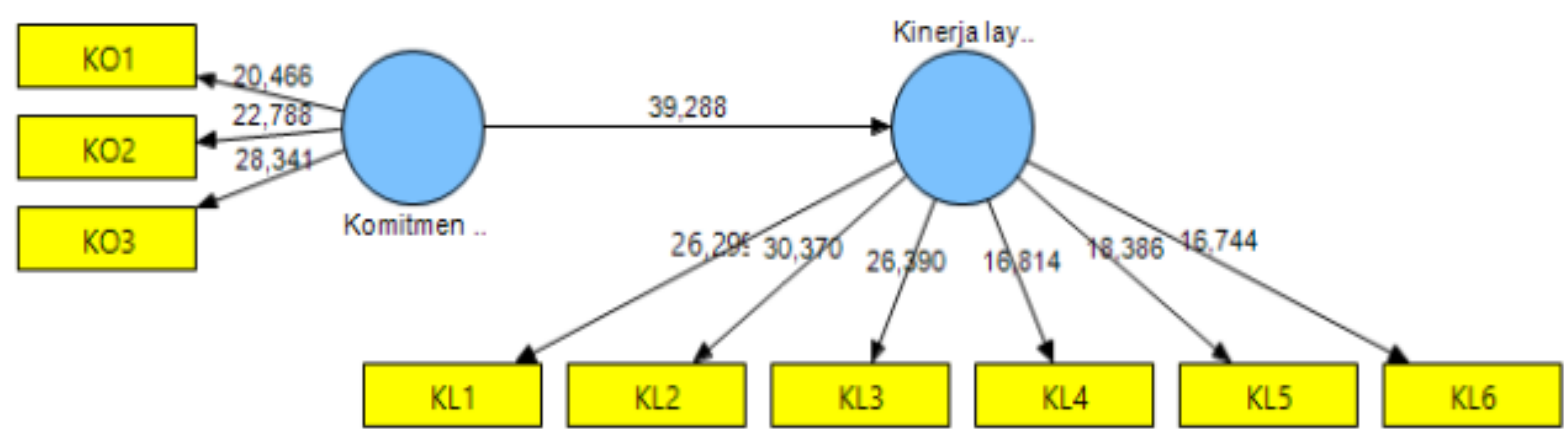

Figure 2: Full Inner Model

Figure 2 presents that the structural model test is seen through the results of the structural path coefficients. It will answer the formulation of the hypothesis and the significant relationship proposed in this study, the analysis process employed the Smart PLS 2.0 M3 Software (Ringle et al., 2005). The results of the path coefficients are shown in Table 2 below:

Table 3. Measurement Model Results

\begin{tabular}{lllll}
\hline & $\begin{array}{l}\text { Original } \\
\text { Sample }(O)\end{array}$ & Sample Mean $(M)$ & $\begin{array}{l}\text { Standard } \\
\text { Deviation } \\
(\text { STDEV })\end{array}$ & T-Statistics \\
\hline $\begin{array}{l}\text { Organizational } \\
\quad \text { Commitment } \rightarrow\end{array}$ & 0.865442 & 0.875390 & 0.022028 & 39,288017 \\
$\quad \begin{array}{l}\text { Service Performance } \\
\text { Semp }\end{array}$ & & & &
\end{tabular}

Source: Primary Data Processed in 2020

Table 3 shows that there is a positive and significant correlation between organizational commitment to service performance with the $\mathrm{T}_{\text {statistic }}$ value greater than the $\mathrm{T}_{\text {table }}\left(\mathrm{T}_{\text {statistik }} 39.288>\right.$ $\mathrm{T}_{\text {table }}$ 1.976) at a significance level of $5 \%(0.05)$. Thus, this research succeeds in showing that there is a relationship between organizational commitment to health service performance in Sorong Regency. Hypothesis 1 in this study is accepted.

\section{Discussion}

The result obtained from the study showed a positive and significant effect on Organizational Commitment in improving the performance of health services at the Public Health Centers in Sorong regency $\left(\mathrm{T}_{\text {statistik }} 39,288>\mathrm{T}_{\text {tabel }}\right.$ 1,976). These results provide an important 


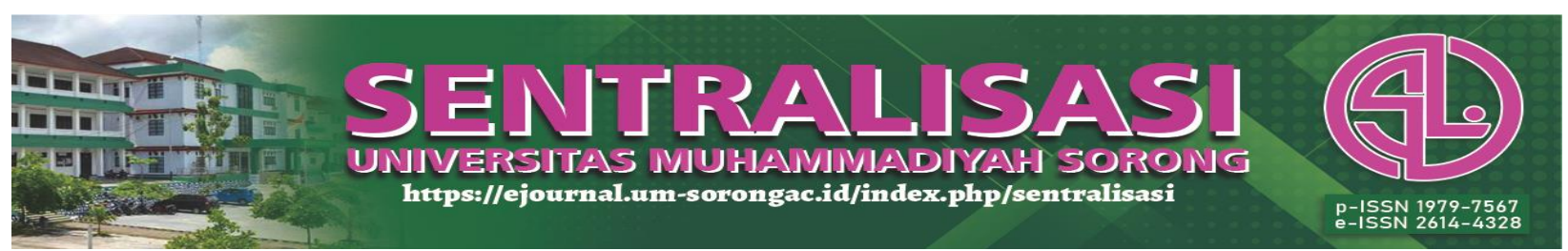

emphasis on improving the performance of health services in health centers, requiring a high commitment (consensus) from employees which is constructed on indicators of feeling proud of the organization, concern for the organization, and the ability and desire to do the effort for the organization (Ivancevich, J., Konopaske, R., \& Matteson, 2012). The study results are in line with the research findings of Adekola, (2012); Muhyi, (2010); Nurhaida et al., (2019) argued that organizational commitment became the main catalyst in improving performance. However, opinions differ from the results of the study by Menon et al., (1996); Sarwat et al., (2011; Subejo, (2013) suggested that organizational commitment does not affect improving organizational performance and service performance.

This scholarly research is also supported by the research conducted by Fu \& Deshpande, (2014) and Almutairi, (2015) which found that commitment has a positive and significant effect in mediating performance enhancement. Herscovitch \& Meyer, (2002) and Moynihan \& Pandey, (2007) organizational commitment is the manifestation of a strong attachment from within a person to side with his organization for the sake of goals and to defend himself in the organization. Furthermore, Meyer et al., (2012) stated that employees who have a high relationship with their organization are a clear reflection of their interests and recognition of contributions, therefore the commitment that is presented is a social standard in an organization referring to a personal realization regarding the importance of their appreciation to the organization. Organizations must build a high commitment relationship because it is one of the most important issues for managers in fostering long-term employee relationships. To create professional services, managers should sustain to strive to increase employees' commitment as it relates to employee retention in generating good services for society. Therefore, organizational commitment is the essential component and affects improving service performance.

Service performance is the work output obtained by a person or group in the organization, accompanied by individual authority and responsibility to trigger the achievement of superior work targets in realizing the vision. These findings are consistent with the research result by Sichtmann \& Von Selasinsky, (2010) which reveals that efforts to improve performance require a strong commitment. Service performance is related to employee work processes, therefore, the health center as an organization should carry out everything according to the existing plan to achieve a competitive advantage, the two employees should be committed to being responsibly involved in their main duties, and the third, Public Health Center as an organization is obligated to focus on the great benefits of existing resources so that from this concern can maximize all activities to gain competitiveness and achieve what the organization's vision is (Keban, 2004). This study supports research from Khunsoonthornkit \& Panjakajornsak, (2018); Klein et al., (2012); Zablah et al.,

Reijeng Tabara 


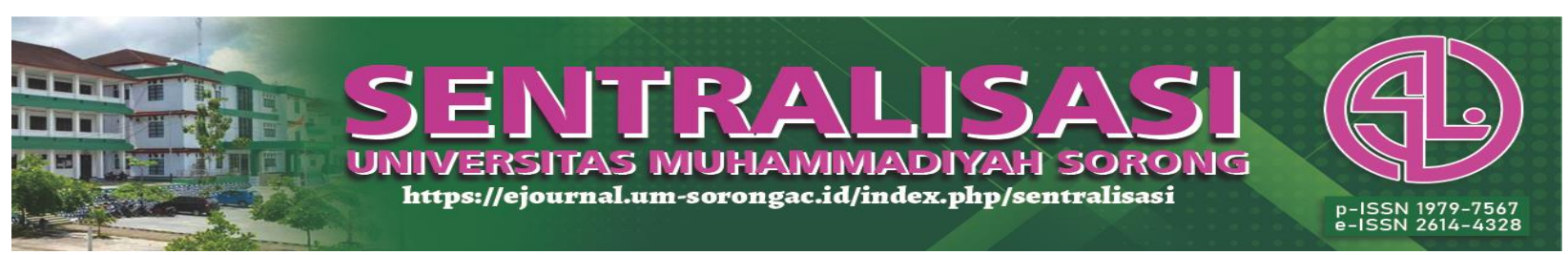

(2012) which comprehensively explains that organizational commitment affects organizational service performance.

\section{Conclusion}

The recent research extends the theory and empirical research that there is a significant relationship between organizational commitment to service performance. The results of this study indicate that the higher the organizational commitment of employees, the more the performance of health services at the health center in Sorong regency will improve. A high organizational commitment which is established by a feeling of pride in the organization, concern for the organization, ability, and a strong desire to do efforts for the organization will trigger employees at the Public Health center to sustain to prioritize organizational interests over personal interests. Hence, organizational commitment is a construct that is presented in employees to run the organization while achieving a prime health center service performance. The results of this study provide the theoretical basis and policies of stakeholders in all health centers in Sorong regency to continue to foster increased organizational commitment for health workers in a sustainable manner providing health services in Public Health Center in Sorong regency.

\section{Acknowledgment}

Researchers would like to thank the Directorate of Research and Community Service, Directorate General of Research and Development Enhancement of the Ministry of Research, Technology and Higher Education for research grants to the Beginner Lecturer Research scheme for the 2020 fiscal year.

\section{References}

Adekola, B. (2012). The Impact of Organizational Commitment on Job Satisfaction: A Study of Employees at Nigerian Universities. International Journal of Human Resource Studies. https://doi.org/10.5296/ijhrs.v2i2.1740.

Agarwal, S., Krishna Erramilli, M., \& Dev, C. S. (2003). Market orientation and performance in service firms: Role of innovation. Journal of Services Marketing. https://doi.org/10.1108/08876040310461282.

Almutairi, D. O. (2015). The Mediating Effects of Organizational Commitment on the Relationship between Transformational Leadership Style and Job Performance. International Journal of Business and Management. https://doi.org/10.5539/ijbm.v11n1p231.

Chung, B. G., \& Schneider, B. (2002). Serving multiple masters: Role conflict experienced by service employees. Journal of Services Marketing. https://doi.org/10.1108/08876040210419424.

Das, T. K., \& Teng, B. S. (2000). A resource-based theory of strategic alliances. Journal of Management. https://doi.org/10.1177/014920630002600105.

Ferdinand, A. (2011). Metode Penelitian Manajemen Pedoman Penelitian untuk Penulisan Skripsi 


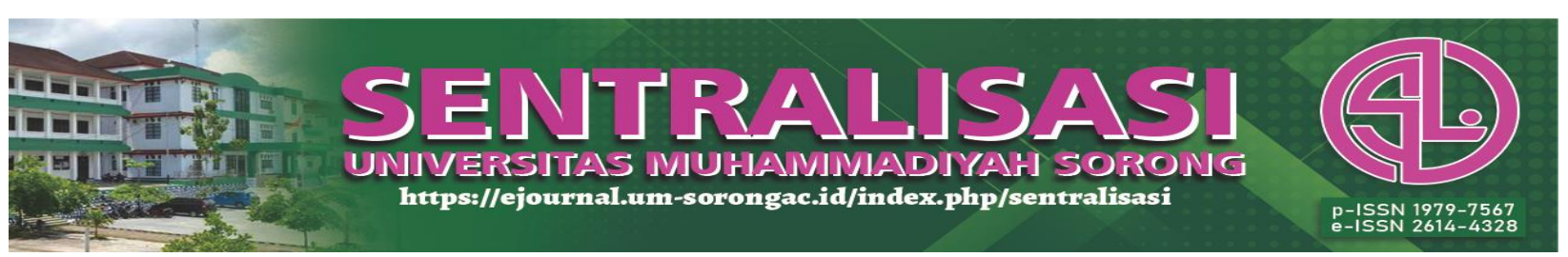

Tesis dan disertai Ilmu Manajemen. In Semarang: Universitas Diponegoro.

Fu, W., \& Deshpande, S. P. (2014). The Impact of Caring Climate, Job Satisfaction, and Organizational Commitment on Job Performance of Employees in a China's Insurance Company. Journal of Business Ethics. https://doi.org/10.1007/s10551-013-1876-y.

Hair, J. F.; Black, W. C.; Babin, B. J.; Anderson, R. E. (2014). Multivariate Data Analysis. In Statistica Neerlandica. https://doi.org/10.1111/j.1467-9574.1962.tb01184.x

Herscovitch, L., \& Meyer, J. P. (2002). Commitment to organizational change: Extension of a three-component model. Journal of Applied Psychology. https://doi.org/10.1037/00219010.87.3.474.

Huang, P.-F., \& Dai, C.-W. (2010). The impacts of emotional contagion and emotional labor perception on employees' service performance. International Journal of Electronic Business Management.

Ivancevich, J., Konopaske, R., \& Matteson, M. (2007). (2012). Organization Behaviour and Management. In McGraw-Hill.

Karatepe, O. M. (2013). High-performance work practices and hotel employee performance: The mediation of work engagement. International Journal of Hospitality Management. https://doi.org/10.1016/j.ijhm.2012.05.003.

Keban, Y. T. (2004). Enam Dimensi Strategis Administrasi Publik: Konsep. In Teori dan Isu, Yogyakarta: Gava Media.

Khunsoonthornkit, A., \& Panjakajornsak, V. (2018). Structural equation model to assess the impact of learning organization and commitment on the performance of research organizations. Kasetsart Journal of Social Sciences. https://doi.org/10.1016/j.kjss.2018.07.003.

Klein, H. J., Molloy, J. C., \& Brinsfield, C. T. (2012). Reconceptualizing workplace commitment to redress a stretched construct: Revisiting assumptions and removing confounds. Academy of Management Review. https://doi.org/10.5465/amr.2010.0018.

Kotler, P. (2012). Marketing management/Philip Kotler, Kevin Lane Keller. Pearson Education International.

Kozlenkova, I. V., Samaha, S. A., \& Palmatier, R. W. (2014). Resource-based theory in marketing. In Journal of the Academy of Marketing Science. https://doi.org/10.1007/s11747-013-03367.

Menon, A., Bharadwaj, S. G., \& Howell, R. (1996). The quality and effectiveness of marketing strategy: Effects of functional and dysfunctional conflict in intra organizational relationships. Journal of the Academy of Marketing Science. https://doi.org/10.1177/0092070396244002.

Meyer, J. P., Stanley, L. J., \& Parfyonova, N. M. (2012). Employee commitment in context: The nature and implication of commitment profiles. Journal of Vocational Behavior. https://doi.org/10.1016/j.jvb.2011.07.002.

Moynihan, D. P., \& Pandey, S. K. (2007). Finding workable levers over work motivation: Comparing job satisfaction, job involvement, and organizational commitment. Administration and Society. https://doi.org/10.1177/0095399707305546

Muhyi, H. A. (2010). THE INFLUENCE OF ORGANIZATIONAL CULTURE AND 


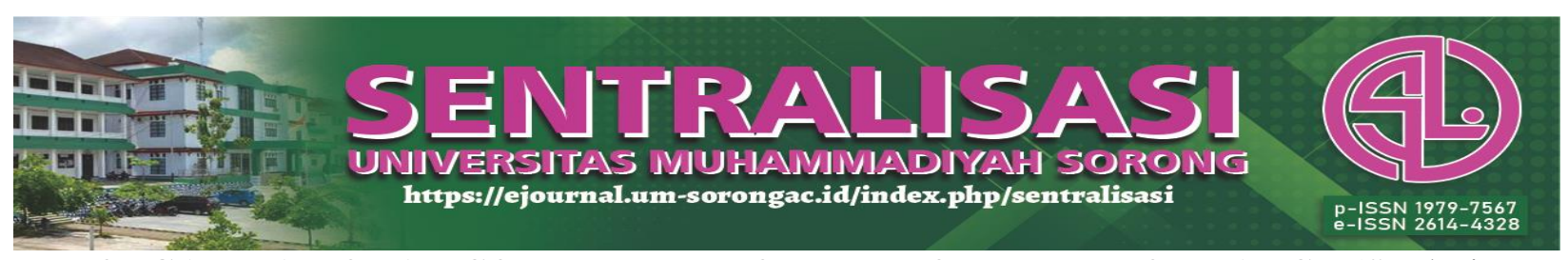

ORGANIZATIONAL COMMITMENT ON EMPLOYEE PERFORMANCE (Study in PT Pelayaran Samudera Selatan Jakarta). Strategic: Jurnal Pendidikan Manajemen Bisnis. https://doi.org/10.17509/strategic.v10i2.1081.

Nurhaida, N., Evanita, S., \& Patrisia, D. (2019). The Influence of Organizational Culture, Job Satisfaction and Organizational Commitment on Employee Performance in Padang Panjang City Government. https://doi.org/10.2991/piceeba2-18.2019.44.

Parasuraman, a, Zeithaml, V. a, \& Berry, L. L. (1988). SERQUAL: A Multiple-Item scale for Measuring Consumer Perceptions of Service Quality. In Journal of Retailing. https://doi.org/10.1016/S0148-2963(99)00084-3

Porter, M. E., Johanson, J., Vahlne, J.-E., Wiedersheim-Paul, F., Madsen, T. K., Servais, P., Lu, J. W., Beamish, P. W., Coe, N. M., Taylor, P., Dunning, J. H., Prahalad, C. K., Hamel, G., Hitt, M. A., Ireland, R. D., Hoskisson, R. E., Osland, G. E., Taylor, C. R., Zou, S., ... Voss, H. (2007). Strategic Management Competitiveness and Globalization Concepts and Cases. In Journal of International Business Studies.

Ringle, C. M., Wende, S., \& Will, S. (2005). SmartPLS 2.0 (M3) Beta. Hamburg.

Sarwat, N., Hayat, K., Qureshi, J. A., Ali, M., Nosheen, S., Khansa, H., Javeria Ashfaq, Q., \& Mehvish, A. (2011). Impact of strategic leadership on organizational performance, in the context of job satisfaction and organizational commitment, evidence from educational institutions of Pakistan. Interdisciplinary Journal of Contemporary Research In Business.

Shaw, J. D., Park, T. Y., \& Kim, E. (2013). A resource-based perspective on human capital losses, HRM investments, and organizational performance. Strategic Management Journal. https://doi.org/10.1002/smj.2025

Sichtmann, C., \& Von Selasinsky, M. (2010). Exporting services successfully: Antecedents and performance implications of customer relationships. Journal of International Marketing. https://doi.org/10.1509/jimk.18.1.86

Subejo, S. (2013). The Effect of Organizational Commitment and Organization Identity Strength to Citizenship Behaviour (OCB) Impact On Fire Department and Disaster Employee Performance in Jakarta Indonesia. IOSR Journal of Business and Management. https://doi.org/10.9790/487x-1033036

Zablah, A. R., Franke, G. R., Brown, T. J., \& Bartholomew, D. E. (2012). How and when does customer orientation influence frontline employee job outcomes? A meta-analytic evaluation. In Journal of Marketing. https://doi.org/10.1509/jm.10.0231 